\title{
The wound which will not close: Jan Patockka's philosophy and the conditions of politicization
}

\section{Daniel Leufer}

\section{Studies in East European Thought}

ISSN 0925-9392

Volume 69

Number 1

Stud East Eur Thought (2017) 69:29-44

DOI 10.1007/s11212-017-9273-1

\section{STUDIES IN}

EAST EUROPEAN

THOUGHT

Formerly Studies in Soviet Thought

\section{Springer}


Your article is protected by copyright and all rights are held exclusively by Springer Science +Business Media Dordrecht. This e-offprint is for personal use only and shall not be selfarchived in electronic repositories. If you wish to self-archive your article, please use the accepted manuscript version for posting on your own website. You may further deposit the accepted manuscript version in any repository, provided it is only made publicly available 12 months after official publication or later and provided acknowledgement is given to the original source of publication and a link is inserted to the published article on Springer's website. The link must be accompanied by the following text: "The final publication is available at link.springer.com". 


\title{
The wound which will not close: Jan Patočka's philosophy and the conditions of politicization
}

\author{
Daniel Leufer ${ }^{1}$
}

Published online: 2 March 2017

(C) Springer Science+Business Media Dordrecht 2017

\begin{abstract}
This article investigates the political potentialities of Jan Patočka's philosophy. It begins by situating Patočka's philosophy in the context of the history of Czechoslovakia, and poses the question of whether Patočka's late Kantianism and involvement with the Charter 77 initiative constitutes the sole political potentiality of his philosophy. It then argues that Patočka's status as a political thinker is best understood by demarcating his pre-political philosophical core from its possible political applications. By sketching the essence of his philosophy as a conception of 'ontological wounding', the article then investigates how this core of his philosophy can be politicized in certain circumstances. Ultimately, it argues that Patočka should not be considered a political thinker per se, but that his philosophy nevertheless has political potentialities.
\end{abstract}

Keywords Jan Patočka $\cdot$ Charter $77 \cdot$ Human rights · Socrates · Political phenomenology $\cdot$ Dissidence

\section{The political test}

\section{The philosopher in dark times}

In a seminar given towards the end of his life and published in transcript as The Spiritual Person and the Intellectual, ${ }^{1}$ Jan Patočka takes up one of the central

\footnotetext{
1 In Czech the title is Duchovní člověk a intelektuál. The terms duch and its cognates correspond to the German Geist, and hence carrying a meaning which encompasses both the English 'spiritual' but also 'of

Daniel Leufer

DanielJohn.Leufer@hiw.kuleuven.be

1 Husserl-Archives: Centre for Phenomenology and Continental Philosophy, Higher Institute of Philosophy, KU Leuven, Kardinaal Mercierplein 2, Box 3200, 3000 Leuven, Belgium
} 
themes of phenomenology, indeed of philosophy in general: the relationship of the person to the world. Taking Plato as his starting point, Patočka says that what separates the true philosopher (or more broadly the 'spiritual person') from the ordinary human is precisely their relationship to the given world: "The philosopher differs from others in that the world, for him, is not self-evident." (Patočka 2007b, p. 53) Whereas in everyday life the ordinary person's relationship to the world is unproblematic and stable, the spiritual person lives in a problematic relationship with the world. Patočka variously describes this relationship as a state of unanchoredness or uprootedness, as a 'shaking' of our naïve sense of the meaningfulness of existence. According to Patočka, experiences which cause this fundamental shaking are rare in comparison to our everyday experiences which rather confirm and bolster the meaning of the world as we know it. Listing the types of experiences which can occasion such a loss of foundation, Patočka mentions betrayal by friends, the death of loved ones and, significantly, "experiences of the collapse of entire societies." (Patočka 2007b, p. 54)

Regardless of what other trials he had undergone, the last of these was something which Jan Patočka had experienced four times by the end of his life. First, at the age of eleven, he witnessed the collapse of the Austro-Hungarian Empire and the emergence of the new state of Czechoslovakia under the leadership of its philosopher-king, Tomáš Masaryk. This was to be, arguably, his only positive experience of societal collapse. Twenty years later, he saw the state founded by Masaryk effectively destroyed by the signing of a piece of paper in Munich. With that capitulation to Hitler, the little Czechoslovak nation was abandoned by the democratic states of Western Europe and brought under Nazi dominion. Then, ten years after the Munich Agreement, the communist coup of 1948 undid whatever scraps of democracy had been reconstructed after the Second World War, instituting almost twenty years of unbroken oppression and intolerance. Finally, in 1968, the optimism of the reforms leading up to the Prague Spring was crushed as the Soviet tanks rolled into re-establish totalitarian oppression and smother whatever freedom had emerged under Alexander Dubček's leadership.

The crushing of the Prague Spring led to a period of oppression and hopelessness, commonly referred to as 'normalization' (for a historical account of this period see Bolton 2012). In April of 1975, the same year in which Patočka delivered the aforementioned seminar, the dissident playwright (and future post-1989 president) Václav Havel wrote an open letter to Dr. Gustav Husák, who was at the time the general secretary of the Czechoslovak Communist Party (Havel 1992). In the letter, Havel provides a vivid description of the downtrodden condition of his nation's soul, of how the government's attempt to supress all resistance has created an environment in which truth is choked and deceit prevails:

It is as though after the shocks of recent history, and the kind of system subsequently established in this country, people had lost all faith in the future, in the possibility of setting public affairs right, in the meaning of a struggle for

Footnote 1 continued

the mind' or 'intellectual'. In this particular essay, Patočka contrasts the 'duchovní' person to the intellectual. 
truth and justice. They shrug off anything that goes beyond their everyday, routine concern for their own livelihood; they seek ways of escape; they succumb to apathy, to indifference toward suprapersonal values and their fellow men, to spiritual passivity and depression. (Havel 1992, p. 57)

And yet, despite the tumultuous, punishing, and oppressive conditions through which Patočka had lived up to this point, he never seems to have given up hope. In the seminar from 1975, surrounded by the misery which Havel describes in his letter, Patočka still affirms that "the spiritual person today has no reason for resignation. The spiritual person can once again see certain possibilities. The spiritual person must cease being afraid, and the basis for him not to be afraid lies precisely in that which he is able to catch glimpse of." (Patočka 2007b, p. 63) Indeed, throughout his career, we can note the persistence of one of his most fundamental philosophical convictions: namely, that there is always a possibility for a person to transcend their situation towards something higher, towards that which makes us 'truly human'. Although some of his later texts-for example the sixth of his Heretical Essays - do tend towards what one commentator referred to as "the dark romanticism of Nietzsche and Heidegger," (Erazim Kohák in his Translator's Postscript to Patočka 1996, p. 157) Patočka seems to have maintained a conviction, or perhaps faith, that no darkness can ever fully extinguish the philosophical illumination which is the heritage passed down from the ancient Greeks.

Although Patočka displays a resilience to pessimism throughout these dark times, in his final 'political' texts he goes beyond this minimal faith to express an astonishing degree of moral conviction. These final texts were written in response to the publication of Charter 77, the dissident declaration in defence of human rights published in 1977 (for an account of the Charter and its diverse signatories, see Bolton 2012). ${ }^{2}$ The text of the Helsinki Final Act, signed by the Czechoslovak government in 1975, specified that the "participating States will respect human rights and fundamental freedoms, including the freedom of thought, conscience, religion or belief, for all without distinction as to race, sex, language or religion." (appendix to Robertson 1977, p. 48) In signing the Helsinki Accords and then in ratifying the two United Nations Covenants on Human Rights in March 1976, the Czechoslovak government had agreed to respect the basic human rights of its citizens, and the Charter aimed to hold them to that. ${ }^{3}$ As one of the three principal spokespersons for the Charter (along with Václav Havel and Jiří Hájek), Patočka came under attack from the Czechoslovak government, undergoing intense interrogations and being subjected to defamatory attacks in the press.

In these texts, which Patočka wrote in response to the publication of (and reaction to) Charter 77, we find him advocating an absolute morality which seems to be at odds with his previous philosophy:

\footnotetext{
${ }^{2}$ Patočka's main Charter 77 texts which are available in English are the following: The Obligation to Resist Injustice (Patočka 1989a), What We Can and Cannot Expect from Charter 77 (Patočka 1989b), and What Charter 77 is and What it is Not (Patočka 1981).

${ }^{3}$ For a nuanced legal analysis of exactly what the Helsinki Final Act and the ratification of the Covenants committed the government to, see Robertson 1977.
} 
If human development is to match the possibilities of technical, instrumental reason, if a progress of knowledge is to be possible, humankind needs to be convinced of the unconditional validity of principles which are, in that sense, "sacred," valid for all humans at all times, and capable of setting out humanity's goals. We need, in other words, something that in its very essence is not technological, something that is not merely instrumental: we need a morality that is not merely tactical and situational but absolute. (Patočka 1989a, b, p. 340)

In this passage we have Patočka's familiar description of the 'technical age' as an age in which instrumental reason dominates (see for example the fifth heretical essay in Patočka 1996). What is unfamiliar, however, is the invocation of principles which are valid for humans at all times, the invocation of an absolute morality. Indeed, in these Charter texts Patočka quite clearly invokes Kantian moral ideas (albeit in an idiosyncratic fashion), leading some commentators to speak of a late 'Kantian turn' in Patočka's thinking (Čapek 2009). The question of the compatibility of this absolute morality with Patočka's previous philosophy has therefore been justly raised (see Tucker 2000 and Čapek 2009). Whereas some (such as Mensch 2011 and Mensch 2016) find a perfect coherence between Patočka's earlier philosophical position and his involvement in the Charter, others see an uneasy fit between the Kantian assertions of the Charter texts and Patočka's previous work.

Let us begin with the following questions: firstly, in what sense can we speak of a Kantian turn in Patočka's Charter texts? secondly, can Patočka's position in his late texts be reconciled to his previous philosophy? ${ }^{4}$

\section{A Kantian turn?}

To clearly illustrate the discrepancy between Patočka's previous thinking and his assertions in these Charter texts, let us briefly look at a seminar which he gave in 1973, the fourth of the Four Seminars on the Problem of Europe. In this discussion with students, Patočka speaks about the Russian dissidents Andrei Sakharov and Aleksandr Solzhenitsyn, ${ }^{5}$ singling them out as individuals whose opposition to totalitarian repression perfectly embodies his ideal of authentic resistance. According to Patočka, the ultimate significance of their protest—or what he refers to as their 'sacrifice' - is the following:

to show in concreto that freedom is something negative, to show the positivity of this negative quantity. Only if man is able to see this - and not only see it, but to carry it through to the end - will it be possible to show that in the world and in life there exists something like difference (Patočka 2002b p. 416) ${ }^{6}$

\footnotetext{
${ }^{4}$ Of course, this touches on a deeper question of the extent to which we can speak of Patočka having a unified, consistent philosophy. This question is, of course, far too broad to be answered here.

5 Patočka elsewhere refers to Sakharov and Solzhenitsyn as 'heroes of our time,' along with J. Robert Oppenheimer, Jean-Paul Sartre, and Martin Heidegger (see 'Les héros de notre temps' in Patočka 1990).

6 My translation is directly from the Czech original.
} 
The 'difference' to which Patočka refers here is, of course, the Heideggerian ontological difference, the difference between being (Sein) and beings (Seiende). By sacrificing their livelihoods and bringing the wrath of the establishment down upon them, Patočka claims that the Russian dissidents disrupt the instrumental rationality which defines the contemporary era. In disrupting the Gestell of modern existence, their sacrifice points to an authentic understanding of the meaning of being.

Coming back to Patočka's characterisation of the Russian dissidents, it is evident that he sees a fundamental opposition between their resistance and a resistance based on a universal, timeless principle such as the categorical imperative: "Through what they do, these men at the same time show that it is not about a general [obecný] formula, such as the categorical imperative, but about something which only has power and validity [uplatnění] in a concrete historical situation." (Patočka 2002b, p. 416) Here, then, Patočka seems to reject the validity of the same universal and timeless principles which he defends in his later Charter texts. On this basis, it does seem that there is a fundamental 'turn' between this text and the later Charter text. However, before making such a conclusion we must look more closely at how Patočka characterises the relationship between the ontological difference and the categorical imperative.

In reality, Patočka's position is more nuanced than a blunt rejection of the categorical imperative. Indeed, rather than see an irreconcilable opposition between the categorical imperative and the ontological difference, Patočka sees the categorical imperative as a deficient expression of the ontological difference:

What this concerns is the most authentic form in which the difference is manifested between being and what beings opens to us. The question is whether this is the categorical imperative, whether the categorical imperative is the most adequate expression of this [difference]. It is the characteristic form of a certain epoch, an undoubtedly inadequate form - because of its nonhistorical character [nehistoričnost]. It is a historical form in its ahistorical historicity [historická ahistoričnost]. (Patočka 2002b, p. 419)

In a very un-Kantian interpretation of the categorical imperative, Patočka here claims that it is historically irrelevant precisely because of its claim to ahistoricity; paradoxically, its claim to relevance in all situations is precisely what makes it only relevant in one historical situation. For Patočka, Kant's epoch was one in which such an appeal to transcendent truth was both legitimate and relevant. However, he characterises his own epoch-and I presume more particularly the situation on his side of the Iron Curtain-as one in which such an appeal no longer makes sense. In this post-metaphysical epoch, a different sort of protest is required, and that is what he sees exemplified in Sakharov and Solzhenitsyn. Nevertheless, Patočka respects the spirit of Kant's morality, and sees the Russian dissidents as the vanguard of the same tradition in which Kant operated. What is essential to note here is that Patočka sees Kant's categorical imperative and Heidegger's ontological difference as two historically determined expressions of a philosophical insight which stretches back to the Ancient Greeks. For Patočka, the history of philosophy is a complex interplay between philosophers and the concrete historical situations in which they live: philosophy looks to eternity, but lives in history. As I will argue in what follows, we 
need to understand Patočka precisely in this interaction with his situation but also within this lineage of philosophy which goes back to (at least) Socrates.

However, even bearing in mind the eminently historical character of Patočka's conception of philosophy it does seem strange that in 1976/1977 he would revert to a principle which he previously declared irrelevant to his epoch. Does his thinking undergo a radical Kantian turn, or can the turn to Kantianism be understood as consistent with this earlier position? Was there some fundamental change in the historical situation to make Kantain morality relevant once more? In order to answer these questions, it will be instructive to turn to an article by Jakub Čapek on precisely this topic, 'Le devoir de l'homme envers lui-même: Patočka, Kant et la Charte 77.'

In this excellent article, Jakub Čapek pointedly addresses the question of Patočka's turn to a form of Kantianism in his final texts. He investigates the possible philosophical motivation or background (arrière-fond) which could have led Patočka to his defence of human rights in Charter 77. According to Čapek, we can find three such motivations within Patočka's work, all of which could acquire political meaning in certain circumstances: these are what Čapek calls the Socratic motivation, the motivation of shakenness, and the Kantian motivation. Although the latter is only to be found in Patočka's Charter texts, Capek rightly states that Patočka's Socratism and his notion of shakenness appear throughout his career. ${ }^{8}$

Following this, Čapek proceeds to discount the Socratic motivation and the motivation of shakenness as possible foundations for Charter 77. With regard to the Socratic motivation, he says that "even if this attitude could receive a political meaning in certain circumstances, it is too open and negative to provide a positive foundation for an action such as that of Charter 77." (Čapek 2009, p. 353) Comparing this to Patočka's discussion of Sakharov and Solzhenitsyn from the 1974 seminar, we see a contrast. Whereas Čapek claims that the openness and negativity of Patočka's Socratism prevent it from grounding political action, in 1974 Patočka claims that the precise value of the Russian dissidents' political protest lies in its negativity: "It is this no, which is more powerful than a direct yes, that these men realise in concreto, in a discreet and unemotional form, but with an intention which is perfectly clear and considered." (Patočka 2002b, p. 416) It thus seems strange that for his own political action, Patočka would have to abandon the very thing which he admired in the political action of the Russian dissidents: namely, the radical negativity of their rejection of the political order. For now, let us simply note this tension.

Concerning the inability of Patočka's idea of shakenness to ground the Charter, Capek lists two reasons but indicates that there are others. He points to the fact that in the text in which this notion of shakenness plays its greatest role, namely, the Heretical Essays, Patočka puts forward a position with two features which disqualify it from serving as the basis for a defence of human rights. Firstly, Patočka

\footnotetext{
7 The article is published in French, all quotations are my own translations.

8 This is not, of course, to say that Patočka never refers to Kant throughout his career. Kant is a regular interlocutor for Patočka, but when it comes to morality, Patočka typically accuses Kant of a failure to grasp human historicity (see the previously quote passages from Patočka 1990, for example).
} 
collapses the difference between Western liberal democracies (which respect human rights) and Eastern totalitarian communist societies (which do not respect human rights), claiming them both to be manifestations of the same drive towards 'total mobilization'.9 Secondly, Patočka here puts forward an understanding of technology which Čapek concludes is incompatible with a basic conception of political accountability. For Patočka, the great tragedies and innumerable fatalities of the twentieth century "are seen as the consequences of a certain ontology adopted by humanity as a whole [since the 16th century] and not as deeds which are the due to anybody in particular. To put it another way, misdeeds cease to be deeds; they thus cease to be attributable to somebody who would have committed them." (Čapek 2009 , p. 354) ${ }^{10}$ Within the context of the Heretical Essays, Patočka's philosophy of history seems to present the tragedies of the twentieth century as inevitable consequences of the dominant ontology of modernity. Insofar as Patočka's notion of shakenness is fundamentally tied to the position presented in the Heretical Essays, Capek claims that it is insufficient to act as the foundation of a conception of human rights.

Following his dismissal of the Socratic motivation and the motivation of shakenness, Capek goes on to furnish a nuanced and enlightening analysis of Patočka's late Kantianism. Čapek provides a convincing analysis of Patočka's interpretation of Kant's 'duties towards oneself' and the manner in which Patočka uses this in his support of the Charter. Although I cannot do justice to the complexity of his argument here, Čapek's conclusion is that Patočka's 'Kantianism' is indeed compatible with his career-long conception of negative freedom, ${ }^{11}$ and that it provides the necessary means to move beyond this negativity towards the Charter's positive plea for human rights. According to Čapek, Patočka's Kantianism in these texts is dictated by circumstances, but not thereby opportunistic or disingenuous: "What is dictated by circumstance is the urgency of giving a positive content to this [negative] idea of freedom." (Čapek 2009, p. 370)

In essence, I find myself in agreement with Capek's conclusion. As regards the question of which aspect of Patočka's philosophy can explain his support of the Charter, then, I think that Čapek has provided us with a satisfactory answer. For Charter 77's concrete advocacy of human rights, Patočka's conception of negative freedom (as expressed in his Socratism and his idea of shakenness) was not a sufficient motivation; this essential negativity needed to be developed towards some positive position. In this concrete instance, an idiosyncratic interpretation of Kant's duties toward oneself provided such a possibility. However, this is certainly not the

\footnotetext{
9 See, for example, p. 114 of the Fifth Essay and p. 125 of the Sixth Essay (Patočka 1996). As I will show later, in another text Patočka shows that he is keenly aware of the difference between the two societal forms and of the precise role of human rights within each.

10 The influence of Ernst Jünger on Patočka' thinking here is decisive. As I have pointed out in a previous article, Patočka runs a distinct danger here of what Lukács would describe as reification (Verdinglichung). In reading the catastrophes of the twentieth century as the results of some abstract ontology, one can clearly argue that Patočka, following Jünger, mystifies their actual origin as the results of concrete human action, making them appear as inevitable instead of as humanly avoidable. See (Lukács 1990), and my article on Patočka's Heretical Essays and the danger of reification: Leufer 2016).

11 For interpretations of Patočka's philosophy as essentially a philosophy of freedom see Tardivel 2011 and also Tava 2015.
} 
last word with regard to the political potential of Patočka's philosophy. What is interesting is that Čapek ultimately concludes that even Patočka's Kantianism should be seen as compatible with his career-long conception of negative freedom (Čapek 2009, p. 370).

In what follows, I will argue that Patočka's idea of negative freedom, his Socratism, and his notion of shakenness all express in different ways one fundamental philosophical attitude (Einstellung). In this sense, I will disagree with Čapek's initial distinction of three potential 'philosophical backgrounds' for Patočka's political action. Instead, I will argue that his Kantianism was but one legitimate political extension of a more foundational idea which is variously expressed as a Socratism, a notion of shakenness, the chorismos of the negative Platonism texts, the third movement of existence, or as a radicalised epoche in Patočka's phenomenological texts. ${ }^{12}$ Specifically, I will argue that what underlies Patočka's philosophy as such is the idea of an ontological difference, ${ }^{13}$ and that any of his more positive developments-such as his late Kantianism-can be understood as attempts to develop this fundamental insight in terms of his own philosophical project(s).

Rather than look at Patočka's explicit discussion of Heidegger and the ontological difference, however, I will focus on the way in which he reads Socrates through Heidegger. I do this because Patočka himself sees Heidegger's ontological difference as the contemporary expression of this fundamental philosophical attitude which begins with Socrates. As such, going through Patočka's Socrates means approaching the idea through what Patočka himself sees as its beginning. One particularly enlightening term which Patočka uses for his 'Socratic ontological difference' is 'ontological wounding', and it is this term which I propose to use here. In what follows, I will therefore investigate what this ontological wound is, and show how it describes the fundamental position which underlies both his notion of shakenness and his late Kantianism. Finally, I will attempt to show what precisely the political potential of this philosophical position is, beyond its one concrete manifestation in the Charter texts.

\footnotetext{
12 An account of the movements of existence can be found in the Heretical Essays and many other works from Patočka's later period. The clearest account of his idea of a radicalised epochē is to be found in his text Epochē and Reduction: Some Observations (Patočka 2015).

13 The implication here is evidently that Patočka ascribes to a fundamentally Heideggerian position. More specifically, I would claim that he accepts the idea of the ontological difference as a starting point for philosophising, but that he does not thereby ascribe to the manner in which Heidegger develops his philosophy beyond this central idea. The complex question also arises here of when Patočka made the 'turn' from Husserl to Heidegger. Although it has been claimed that Patočka only properly accepted Heidegger's philosophy in the late 1940s (see Tardivel 2011), Karel Novotný has convincingly shown that Patočka had in fact not settled on either of his great teachers in his early years, and that while his first book, The Natural World as a Philosophical Problem, may well be seen as Husserlian, he was simultaneously writing texts which were evidently Heideggerian (see Novotný 2012). This is not to say, of course, that Patočka was always essentially Heideggerian. Rather, I would claim that at a certain point Patočka takes this basic Heideggerian understanding of man's relation to being as a cornerstone for his philosophical efforts, even though he diverges from Heidegger beyond this basic idea.
} 


\section{The ontological wound}

\section{Who is Socrates?}

Patočka presents his idea of the ontological wound through his conception of Socrates. As such, we must begin by asking "who is Socrates?" The figure of Socrates recurs as a key motif throughout Patočka's œuvre, from the indirect discussion in a text from 1933, 'Platonism and Politics,' (Patočka 2007a) to his final works such as the Heretical Essays and his Charter 77 texts. However, perhaps his most explicit and developed treatment of the problem of Socrates is to be found in a text from 1949 entitled 'Remarks on the Problem of Socrates' (Patočka 1949). ${ }^{14}$ Originally written in French and published in Revue Philosophique de la France et de l'Étranger, Patočka's text presents itself as a philosophical contribution to the contemporary philological debate surrounding the possibility of reconstructing a genuine 'historical' Socrates. Patočka's principal interlocutor is the Swiss philologist Olof Gigon, to whom he attributes the claim that "the problem of a historical and doxological determination of Socrates, of an even minimally complete reconstruction of his personality and his thought, is a hopeless question." (Patočka 1949, p. 186) Because Gigon believes that the various Socratic doctrines (of Plato, Aeschines, Aristippus etc.) are too diverse to allow a common element to be extracted from them, he believes that we cannot reconstruct the genuine Socratic position.

Patočka, however, is not willing to accept Gigon's conclusion that we are incapable of reconstructing the essence of Socratic philosophy. In order to refute this position, Patočka takes up the challenge laid down by Gigon: "the doctrine of Socrates, if one must isolate it from the Socratic doctrines, must constitute the common element amongst them." (Patočka 1949, p. 189) According to Patočka, Gigon fails to find the common element because he is looking for something to which genuine Socratism is entirely opposed: positive doctrine. In contrast to this, Patočka suggests that the common element is something much subtler, and that "initially it is not very visible, no more than the link which unites the fall of a stone, the movement of the planets and the tides." (Patočka 1949, p. 190)

So just what is this gravitational force which unites the divergent branches of Socratism? For Patočka, the central idea is the Socratic paradox, the so-called 'knowledge of not-knowing'. As a response to Gigon, Patočka traces the essential role played by this idea in the work of various Socratics, arguing that what unites them all is not any particular doctrine in the strong positive sense, but rather a particular understanding of the central philosophical significance of not-knowing:

All the Socratics consider, it seems, the phenomenon of not-knowing as essential in Socratism. They try to grasp it, to explain it, to make it understandable often with the help of categories which are originally foreign to it - with the help of Eleatic and possibly Protagorian dialectic; they try above all to do this in constructing their theories as responses to the Socratic

\footnotetext{
14 The original text is in French; all quotations are my own translations.
} 
not-knowing which is in question, a problem which renews itself, a wound which does not close. There is very little that is common to the Socratics if one looks to doctrine; there is quite a lot as soon as one looks at the other side - it is the Socratic question, a question which claims to do without a response or to be itself better than a response. (Patočka 1949, p. 195-196)

The central idea here is that Socrates inflicts a sort of trauma upon his followers, that he opens a wound which refuses to be closed. As Patočka says later on, what unites the various Socratics is that they are responses to the Socratism of Socrates, attempts to move beyond what seems to be the dead end of a philosophical position which will admit of no definitive positive response.

It is important to note, however, that Patočka does not see the Socratics as rejecting Socrates outright. In this sense the idea of the Socratic question as a wound which will not close is essential. To use Heideggerian language, the Socratic wound shatters the convergence between being and beings, tearing open the ontological difference in a way that can never be fully repaired. There is a clear relation between this idea of the ontological wound and Patočka's discussion of the 'ontological metaphor' in the Heretical Essays:

Now, it is characteristic of humans before history that they understand their entire life in terms of something like an ontological metaphor, that they do not differentiate between the night which is a fact of experience and night as the darkness out of which the lightning of being strikes [...] For them, what-is and being, phenomena and the movement of their manifestation, converge on a single plane. (Patočka 1996, p. 32)

In the philosophy of history propounded in this later text, the birth of philosophy represents the opening of this ontological wound and thus the beginning of the human being's explicit relationship to being as such. Thereby human beings gain access to something beyond the given, yet that 'something higher' provides no firm ground or dogma. Rather, the opening of this wound demands that we strive continually to transcend what is merely given. However, at the same time as Socratic negativity presents a positive possibility of transcending the given, it also opens us to the persistent threat of nihilism.

At several points throughout his œuvre Patočka states that man cannot live with the total absence of meaning; that it is not possible to simply resign oneself to nihilism without being destroyed (see, for example, Patočka 1996, pp. 59-60). As such, there are only a limited number of ways in which we can respond to the Socratic wounding. One option is that we can give into relativism, thereby becoming Sophists who do nothing but play with the ambiguity of the Socratic realisation and pursue our self-interest. Another option is that which Patočka sees as the one favoured by most of the Socratics: we attempt to respond to the Socratism of Socrates with an ontology, we attempt to find firm ground once again. How this ground is established varies from thinker to thinker, and what Patočka sees as dividing the various Socratics is the nature of their response to the problem that unites them. 
The final option is that which Patočka sees as the response chosen by Socrates himself; what we could call the genuinely Socratic response to the Socratism of Socrates:

The Socratic attitude entails an ignorance of the Goal, of the meaning of life, at the same time as a passionate, unshakeable adherence to this Goal and to this meaning. This is what makes for the acuity of the Socratic paradox. (Patočka 1949, p. 209)

Indeed, precisely this impossible struggle is what Patočka considers to be the condition of being truly human. This struggle is what he refers to as the 'care for the soul' and which he considers to be the essence of Socratic philosophy, that which, contrary to Gigon, unites all the Socratics as the common element against which their philosophies try to react:

Since with Socrates what is at stake is something more profound, more fundamental than a doctrine, it is not illogical that we would not possess one. In philosophy, it is not always and above all about formulable and formulated doctrines. These rest on something anterior: a preliminary position-taking in relation to the totality of things, in relation to the universe, a general philosophical attitude. This attitude, this position taking can then express itself through doctrines. (Patočka 1949, p. 213)

The real tension in Patočka's philosophy emerges, then, in trying to articulate the authentic response to this Socratic realisation. In the seminar on the Spiritual Person, Patočka describes the difficulty in the following terms:

Essentially, all of philosophy is nothing other than the development of this problematicity as great thinkers have expressed and grasped it. The struggle to extract out of this problematicity something that emerges from it; to find a firm shore, but then again problematize that which emerges as a shore. (Patočka 2007b, p. 54)

As such, the problem lies in the essential restlessness of philosophy as an activity. Anything which is put forward as a response will ultimately be problematized in its turn and rejected. In the face of such a relentless and probably thankless task, we are rather tempted to indulge in the distraction of 'the everyday' or in what Patočka refers to as the self-abnegation in the 'orgiastic.'

However, it is in the notion of the care for the soul that Patočka sees something like a response to this problem. By accepting the almost hopeless terms of philosophical life, one enters into what Patočka claims is an entirely new movement of existence, a life lived in and for truth. Although that truth is never something of which we have a definitive grasp, the very activity of pursuing it is what 'unifies' our soul, placing our life under the unitary and ultimate goal of pursuing truth. But is this unification enough? How, moreover, would such a new 'movement of existence' manifest itself in our political existence? 


\section{The politicization of the wound}

The question which now emerges is that of the politicization of this fundamental woundedness. As Jakub Čapek pointed out, Patočka's philosophy is something which can be politicized under the right circumstances. Indeed, in the seminar of 1975, Patočka himself clearly explains how this takes place:

The spiritual person is of course not a politician and is not political in the usual sense of this word. He is not a party to the disputes which rule this world - but he is political in yet a different way, obviously, and he cannot be apolitical because this non-self-evident nature of reality is precisely what he throws into the face of this society and of everything that he finds around himself. (Patočka 2007b, p. 63)

In the totalitarian conditions in which this seminar was delivered, what made Patočka's Socratism political was not any particular program of reform which it suggested to those in power. Rather, it was the audacity of a philosophical position which dared to claim access to something higher than the merely given. The philosopher becomes politicized when he throws this problematicity into the face of a political order which bases its power precisely on eradicating all problematicity from social existence. At this point, the mere living in problematicity of the philosopher, his ontological woundedness, threatens to undermine the foundations of the hegemonic regime. What we see in Patočka's conflict with the political order of his time is a perfect and tragic illustration of the fundamental point at which philosophy and politics come into conflict.

Nevertheless, even this conflict with political reality is still fundamentally negative. We can see this very clearly in the sixth of the Heretical Essays when Patočka speaks of how the solidarity of the shaken could manifest itself as a political force: "The solidarity of the shaken can say "no" to the measures of mobilization which make the state of war permanent. It will not offer positive programs but will speak, like Socrates' daimonion, in warnings and prohibitions." (Patočka 1996, p. 135) Here we can see that as long as we remain at the level of Socratic wounding or shakenness, negativity is as far as political engagement can go. In this sense, Čapek was right to argue that it was only Patočka's later turn to Kantianism which allowed him to provide a philosophical grounding for Charter 77. While this Kantianism was not necessarily in conflict with Patočka's more fundamental position, it does pose the interesting question of whether that is the only possible 'turn' which can be taken to move beyond this fundamental negativity. In answer to that question, I believe that we can say that Patočka's Socratism has other political potentialities besides the defence of human rights in Charter 77, and this can be made clear by looking at another seemingly anomalous text written nine years before the publication of the Charter, at a moment of the greatest political significance for the history of Czechoslovakia.

In the text Inteligence a opozice (Intellectuals and Opposition), Patočka discusses the role of the intellectual in political life. First published in 1969, this Czech text is a development of a conference paper which he gave in Germany the previous year under the title Intelligenz und die Opposition. The significance of this text for our 
question has much to do with the circumstances in which it was written. The original paper was given in West Germany two months before the demise of the Prague Spring with the invasion of Czechoslovakia by the forces of Russia and other Warsaw Pact members. In contrast to the situation in which Patočka wrote later texts such as the Heretical Essays, this was a period of great political hope for a Czechoslovak citizen. The reforms of the Prague Spring had allowed previously outcast citizens such as Patočka to resume their role in the public sphere, and the possibility of a genuinely reformed Marxism seemed to be within reach. As such, it is perhaps not surprising that we find Patočka actually supporting socialism in this text. Of course, from the perspective of the Heretical Essays it seems shocking that Patočka could say something such as the following:

The significance of Czechoslovak events in 1968 is that for the first time the possibility of a new free society is taking shape, based on the transformation of the working class - within Socialism itself - into a class which has intellectuals at its core, a core which is capable of introducing society to a new productive and historical era. This society, despite the incomprehension and the pressures to which it has been subjected by the old-style Socialism, has not let itself be persuaded by the suggestion that it represents merely a liberal reaction, but has insisted despite everything on the validity of its own principles for Socialism (Patočka 2016, p. 20)

In light of Patočka's darker writings from the 1970s, it is surprising to see him find such hope in the reformed socialism which was coming into being at the time in Prague. It is significant that the above paragraph was only included in the first edition of the text from early 1969, but was in fact omitted from the second version published later that year. The reason for this omission is clear: Patočka's momentary faith in a positive political movement was violently shattered by the Russian invasion and Dubček's capitulation to his Russian masters. From the moment the tanks rolled into Prague up to the writing of the Heretical Essays, Patočka lived through the dull, punishing desperation of normalization, and the possibility of faith in positive political alternatives had been badly undermined. What is surprising is not the despair of the Heretical Essays, but rather the fact that Patočka managed to put his faith in something positive once again with the Charter.

Another interesting aspect of the text Intellectuals and Opposition is its mention of human rights. In contrast to the talk of absolute principles of morality in Patočka's Charter texts, here we find something seemingly much more in line with the radical negation of all positive principles which we associate with Patočka's Socratism:

The intellectuals of the West have become accustomed to seeing the liberal principles of human rights and freedoms as nothing more nor less than the ideological camouflage of bourgeois regimes, and therefore accord them no importance. The intellectuals of the East, on the contrary, see them as a condition of their own effectiveness as a force of reason penetrating a whole and non-alienated society. Perhaps they overrate them, since none of these principles has an absolute character, and are successful only in a historical 
situation determined by a new structural form of the forces of production. What is important is that we are talking here of different principles; not the abstract principles of supposedly natural freedoms, but principles that, after having been negated, are reborn - born again as conditions under which the government of reason in a totally emancipated society finally becomes possible. (my italics, Patočka 2016, p. 19)

Here Patočka sees the principles of human rights not as absolute, but rather as simply effective in determinate historical situations. Obviously, Patočka must have judged the determinate historical situation of Charter 77 to be one in which these principles would be successful and appropriate. Coming back to Patočka's rejection of the categorical imperative from the 1973 seminar, perhaps we could argue that what made a Kantianism once again relevant in 1976/1977 was precisely the signing of the Helsinki Accords and the ratification of the UN Human Rights Covenants. Because the Czechoslovak government had signed a commitment to uphold human rights, they had created an environment in which the Kantian position was once again relevant as a basis for political action. The Helsinki Accords affirmation of the timeless and absolute principles of human rights provided the grounds for timeless and absolute principles of Kantian morality to be relevant once again: having been 'negated,' they were 'reborn.' Although this may not sound very Kantian, it does offer a way to understand how Patočka himself could move from the position in the 1973 seminar to the position of the Charter texts. It seems that his Kantianism in $1976 / 1977$ was something appropriate to the determinate social situation, just as reformed socialism was appropriate in 1968.

\section{Conclusion}

\section{The courage for positivity}

One could be tempted to see Patočka's changing political orientations as some kind of philosophical opportunism, but I would rather argue that we should see this in light of something we could call the essential dialectic of Socratic politics. What I mean by this is the following: for Patočka, the power of the Socratic wounding, its negativity, is that it allows us to reject all positivity, to reject any given principle or situation. This negativity gives man his abstract freedom, which we could compare to what Hegel called Abstract Right (see \$35-40 'Abstract Right' in Hegel 1991). However, as Hegel taught us, remaining in this abstract right or freedom leads nowhere. Only through taking on a determinate form can one properly enter into political existence. In Patočka's advocacy of reformed socialism in 1968 and in his later advocacy of the human rights of Charter 77, I would argue that we see him taking a 'leap' into positivity. Patočka's Socratism makes no political sense as pure negation; only through a dialectic of leaping into positivity and then back into negation can it become a movement and thereby become a way of life. As Hegel also showed us, remaining in pure negativity is a mere empty freedom, an abstract freedom that can only be abandoned by committing oneself to a determinate 
political existence or to a determinate political position. As such, then, political existence requires what Hannah Arendt recognised as one of the principle virtues of politics: courage (see Arendt 1989, p. 35). From this perspective, Patočka's 'radical negation' as expressed in his negative Platonism, or his notion of the uprooted and shaken existence, are merely the negative side of the coin. Of course, it takes courage to abandon our easy, pre-given meaning in the first place, but it also takes courage to once again abandon this negativity in favour of something determinate.

Nevertheless, to come back to the question of the political potentialities of Patočka's philosophy, one doubt remains. In the seminar Plato and Europe, Patočka speaks of the grand philosophical project, started by Plato, to create a society of justice in which Socrates would not have to die (Patočka 2002a, p. 50). Given his understanding of Socratism, we can say that this is a society in which the practice of 'radical negation' would not conflict with the functioning of political power, in which such questioning would perhaps even be encouraged. As such, we see that the ideal society, for a philosopher, is one which allows the philosopher to exist within it as a philosopher. The question we must ask is whether this is a proper political demand. Indeed, we could see this demand as an instance of what Hannah Arendt referred to as the enmity or hostility (Feindseligkeit) of philosophy towards politics, which she also sees as starting with Plato (Arendt 2013). This enmity is manifested in how philosophy holds itself above politics, disdaining the worldly concerns of the everyday and demanding space for its supposedly higher pursuits. From a critical perspective, we could argue that politics is rather fundamentally about the basic needs of man, and not about higher spiritual needs. This is not a question which can be resolved here, but we can clearly see which side of the argument Patočka advocates.

Ultimately, Patočka's philosophy and his life raise the question of the proper relationship between philosophy and politics. In his case, he chose to confront the polis with the standards of philosophy because the polis was restricting his possibility to live as a philosopher. To take a concrete example, however, in the contemporary European Union the space for true philosophizing is not restricted as it was for Patočka under conditions of normalization in 1970s Czechoslovakia. In this case, then, we arguably lack the conditions in which Patočka's philosophy would take on political significance or power as it did during the time of the Charter. It seems, thus, that the political potential of Patočka's philosophy emerges when politics encroaches upon the proper domain of philosophy. It is doubtful, however, that philosophy conversely has the right to fully encroach on the proper domain of politics outside of these moments of extreme conflict.

\section{References}

Arendt, H. (1989). The human condition. Chicago (Ill.): University of Chicago Press.

Arendt, H. (2013). "What remains? The language remains": A conversation with Günther Gaus (J.

Stambaugh, Trans.). In Hannah Arendt: The last interview and other conversations. Brooklyn: Melville House Publishing. 
Bolton, J. (2012). Worlds of dissent: Charter 77, the plastic people of the universe, and Czech culture under communism. Cambridge, MA: Harvard University Press.

Čapek, J. (2009). Le devoir de l'homme envers lui-même: Patočka, Kant et la Charte 77. Tumultes, no, $32-33,351-370$.

Havel, V. (1992), "Dear Dr. Husák” (Unknown, Trans.). In P. Wilson (Ed.), Open letters: Selected writings 1965-1990 (pp. 50-83). New York: Vintage Books.

Hegel, G. W. F. (1991). Elements of the philosophy of right (A. W. Wood, Trans.). Cambridge: Cambridge University Press.

Leufer, D. (2016). The dark night of the care for the soul-politics and despair in Jan Patočka's sixth heretical essay. In D. Meacham \& F. Tava (Eds.), Thinking after Europe: Jan Patočka and politics. Rowman and Littlefield: Lanham. (forthcoming).

Lukács, G. (1990). History and class consciousness: Studies in marxist dialectics (R. Livingstone, Trans.). London: Merlin Press.

Mensch, J. (2011). Patočka's conception of the subject of human rights. Idealistic Studies, 41(1-2), 1-10.

Mensch, J. (2016). Patocka's asubjective phenomenology: toward a new concept of human rights (Orbis phaenomenologicus. Studien 38). Wurzburg: Königshausen und Neumann.

Novotný, K. (2012). La Genèse d'une hérésie. Monde, corps et histoire dans la pensée de Jan Patočka. Paris, Vrin.

Patočka, J. (1949). Remarques sur le problème de Socrate. In Revue Philosophique de la France et de l'Étranger, T. 139. (pp. 186-213).

Patočka, J. (1981). What Charter 77 is and what it is not. In H. G. Skilling (Ed.), Charter 77 and human rights in Czechoslovakia (pp. 217-219). Allen and Unwin: London.

Patočka, J. (1989a). The obligation to resist injustice (E. Kohák, Trans.). In E. Kohak (Ed.), Jan Patočka: Philosophy and selected writings (E. Kohák, Trans.) (pp. 340-343). Chicago (Ill.): University of Chicago Press.

Patočka, J. (1989b). What we can and cannot expect from Charter 77 (E. Kohák, Trans.). In E. Kohak (Ed.), Jan Patočka: Philosophy and selected writings (E. Kohák, Trans.) (pp. 343-347). Chicago (Ill.): University of Chicago Press.

Patočka, J. (1990). Liberté et sacrifice, (E. Abrams, Trans.). Editions Jérôme Millon, Grenoble.

Patočka, J. (1996). Heretical essays in the philosophy of history, (E. Kohák, Trans.). Chicago: Open Court.

Patočka, J. (2002a). Plato and Europe (P. Lom, Trans.). Stanford (Calif.): Stanford University Press.

Patočka, J. (2002b). Čtyři semináře k problému Evropy. In Jan Patočka (Ed.), Sebrané spisy 3: Péče o duši III. Praha: Oikoymenh.

Patočka, J. (2007a). Platonism and politics (E. Manton, Trans.). In E. Manton (Ed.). Living in problematicity (pp.13-17). Praha: Oikoymenh.

Patočka, J. (2007b). The Spiritual person and the intellectual (E. Manton, Trans.). In E. Manton (Ed.), Living in problematicity (pp.13-17). Praha: Oikoymenh.

Patočka, J. (2015). Epochē and reduction: some observations (M. Bower, I. Chvatik \& K. Maly, Trans.). In L. Učník, I. Chvatik \& A. Williams (Eds.), Asubjective phenomenology: Jan Patocka's project in the broader context of his work (pp. 41-52), Nordhausen: Verlag Traugott Bautz.

Patočka, J. (2016). Intellectuals and opposition. (F. Tava \& D. Leufer Trans.). In D. Meacham \& F. Tava (Eds.), Thinking after Europe: Jan Patočka and politics. Lanham: Rowman and Littlefield.

Robertson, A. H. (1977). The Helsinki agreement and human rights. Notre Dame Law Review, 53(1), 34-48. (article 4).

Tardivel, E. (2011). La Liberté au principe: Essai sur la philosophie de Patočka. Paris: Vrin.

Tava, F. (2015). The risk of freedom: Ethics, phenomenology and politics in Jan Patočka (J. Ledlie, Trans.). Lanham: Rowman and Littlefield.

Tucker, A. (2000). The Philosophy and politics of Czech dissidence from Patočka to Havel. Pittsburgh: University of Pittsburgh. 